\title{
Multiband Stepped Antenna for Wireless Communication Applications
}

\author{
Abdelhalim Chaabane ${ }^{1}$, Omar Mahri ${ }^{1,2}$, Djelloul Aissaoui ${ }^{3,4}$, Nassima Guebgoub $^{1}$ \\ ${ }^{1}$ Université 8 Mai 1945 Guelma, Laboratoire des Télécommunications-LT, Département \\ d'Electronique et Télécommunications, Faculté des Sciences et de la Technologie, Guelma, \\ Algeria \\ ${ }^{2}$ University of Brothers Mentouri Constantine 1, Faculty of Science and Technology, Constantine, \\ Algeria \\ ${ }^{3}$ University of Djelfa, Faculty of Science and Technology, Djelfa, Algeria \\ ${ }^{4}$ University of Tlemcen, Telecommunication Laboratory, Faculty of Technology, Chetouane, \\ Tlemcen, Algeria
}

\begin{abstract}
In this paper, a novel design of a coplanar waveguide fed (CPW) triple-band antenna is introduced. An ultra-wideband (UWB) characteristic is achieved by the initial design through the cut of a stepped shape from the lower part of the initial radiating patch and through the use of a truncated ground plan. To avoid the effects of the electromagnetic interferences with some coexisting wireless communication systems, a transition from the UWB to multiband function is assured by etching a simple circular ring inside the radiating patch. The antenna is printed on the low-cost FR4-substrate having a compact size of $0.162 \lambda 0 \times 0.123 \lambda 0 \times 0.008 \lambda 0$ at $1.57 \mathrm{GHz}$. The design and the analysis of the antenna were done using the commercially software CST Microwave Studio ${ }^{\mathrm{TM}}$ while the fabricated prototype was tested and measured by using a R\&S ${ }^{\circledR}$ ZNB Vector Network Analyzer. The measurements show that the fabricated prototype resonates between $1.57-2.33 \mathrm{GHz}$ (38.97\%), 5.84-6.41 GHz (9.31\%), and 7.93-10.88 GHz (31.37\%). Besides, the proposed antenna has consistent measured radiation pattern characteristics and it also reveals an acceptable realized gain and a high efficiency over the working ranges. Hence, the designed antenna can be a good candidate for many wireless communication systems.
\end{abstract}

Keywords: Multiband antenna; slot antenna; triple-band antenna; coplanar waveguide fed; wireless communication systems

\section{Večpasovna stopničasta antena za brež̌ične komunikacijske aplikacije}

\begin{abstract}
Izvleček: $\vee$ prispevku je predstavljena nova zasnova troplastne antene s koplanarnim valovodom (CPW). Karakteristiko ultraširokega pasu (UWB) dosežemo z rezom stopničaste oblike osnovne zasnove spodnjega dela začetne sevalne krpice in z uporabo zmanjšane talne ravnine. Da bi se izognili učinkom elektromagnetnih motenj nekaterih soobstoječih brezžičnih komunikacijskih sistemov, je zagotovljen prehod z UWB na večpasovno funkcijo z jedkanjem preprostega obroča znotraj sevalne krpice. Antena je natisnjena na poceni substrat FR4 z velikostjo $0,162 \lambda 0 \times 0,123 \lambda 0 \times 0,008 \lambda 0$ pri 1,57 GHz. Načrtovanje in analiza antene sta bila narejena s komercialno programsko opremo CST Microwave Studio ${ }^{\text {TM }}$, medtem ko je bil izdelani prototip testiran in izmerjen z uporabo R\&S ${ }^{\otimes}$ ZNB Vector Network analizatorjem. Meritve kažejo, da izdelani prototip resonira med 1,57-2,33 GHz (38,97\%), 5,84-6,41 GHz (9,31\%) in 7,93-10,88 $\mathrm{GHz}(31,37 \%)$. Poleg tega ima predlagana antena dosledno izmerjene karakteristike vzorcev sevanja in razkriva sprejemljivo ojačenje in visoko učinkovitost $v$ delovnih območjih. Zasnovana antena je lahko dober kandidat za številne brezžične komunikacijske sisteme.
\end{abstract}

Ključne besede: večpasovna antena; režna antena; tropasovna antena; napajan koplanarni valovod; brezžični komunikacijski sistemi

*Corresponding Author's e-mail:chaabaneabdelhalim1979@gmail.com, abdelhalim.chaabane@univ-guelma.dz 


\section{Introduction}

Nowadays, the wireless communication field is one of the important technologies due to many services that offers for our daily life [1]. The Ultra-Wideband (UWB) technologies have acquired an impressive and vast appreciation in the wireless world owing to their advantages. Due to the prompt and vigorous development in the wireless domain, the UWB systems can easily interfered with other co-existing narrowband systems. To avoid potential interferences, the development of multiband antennas has received widespread concentration in recent years for designing efficient compact multi-functional devices [2-4]. Thus, there are strong demands to design multipurpose antennas which should ensure a multiband operation with suitable characteristics, such as: compact structure, low manufacturing cost, low-profile, easy integrating circuit boards and good radiation performances over the working bands [5-6]. Until now, with the use of a variety of techniques, various types of multiband antennas have been presented in the literature for many wireless communication systems application such as those proposed in [5-14]. Among of usual employed techniques to produce multiband function in broadband antennas included the technologies: fractals [7-9], multilayer [10-11], meta-materials [12], stubs loaded [13], slot-etched [14], loading the matching network [15], and radiators coupling [16]. Complex Sierpenski Gasket slots have been introduced in [7] for the production of multiband function. In [8], a multiband antenna has been proposed for IMT2000, GSM1800/1900 and LTE applications; its drawbacks are its large size which is about of $58 \times 40 \times 1.6 \mathrm{~mm}^{3}$, and its very complicated wheel-like fractal structure. In [9], a multiband antenna for mobile terminals application has been proposed; it has large dimensions and uses a complicated binary tree fractal bionic structure to produce only a dualband function. Whilst, a complex multilayer design constructed by periodic structures has been reported in [10] for dual-band application; its big size is another main drawback. A very selective antenna has been proposed in [11] for LTE-R and $5 \mathrm{G}$ lower frequency operations. In addition to the enormous size that presents of about $180 \times 60 \times 3.2 \mathrm{~mm}^{3}$ it has a complicated structure and very sharp working bands. By the incorporation of split ring resonator meta-material loads, a voluminous less efficient antenna which has sharp and close working bands has been proposed in [12]. The same problem of a weak separation between the different bands has been obtained by the designed antenna in [13]. In [14], two thin U-shaped inverted slits etched on a pentagon patch have been presented for WiMAX and WLAN applications where the presented design has good performances but it is large in size. In [15 ], a triple-band ground radiation antenna excited through a Balun has been designed where the voluminous size of the designed structure is about $70 \times 26 \times 0.8 \mathrm{~mm}^{3}$. As well in [16], a multiband antenna has been proposed for many wireless communication systems, but this structure has a large physical size and sharp working bands. Thereby, the antennas mentioned above have complex structures and/or large sizes. Thus, there is a strong need to design simple antennas with reduced size for multi-systems application. A simple compact CPW-fed triple-band antenna for wireless communication systems application is presented in this paper. The triple-band operation is achieved by etching a simple split-shaped circular ring on the radiating element. The designed antenna was firstly calculated and optimized using the commercially software simulator CST Microwave Studio $^{\mathrm{TM}}$. To justify the calculated results, a prototype for the proposed design was realized and measured by $R \& S^{\circledR} Z N B$ Vector Network Analyzer and it also was tested and measured in an anechoic chamber. The main antenna parameters such as current density distributions, voltage standing wave ratio, antenna gain and efficiency are explored.

\section{Antenna geometry and results}

The front view and the dimensions of the proposed multiband antenna are presented in the Figure 1. Its main structure includes a stepped rectangular radiator and a constricted ground plane. To mitigate the effects of the electromagnetic interferences between the UWB systems and some narrow bands co-existing wireless communication systems (Bluetooth, LTE2600, WiMAX, WLAN, and X-band downlink satellite system),

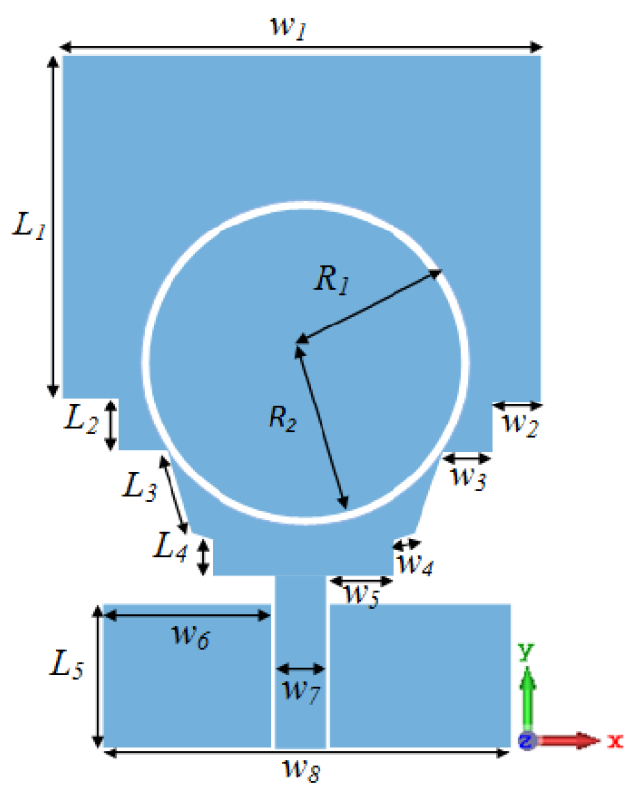

Figure 1: Configuration of the proposed multiband antenna. 
a multiband function is introduced by etching a splitshaped circular ring on the radiating patch. The antenna is designed on a shipper substrate FR4-Epoxy having a relative dielectric constant of 4.4 and an overall size of $0.162 \lambda 0 \times 0.123 \lambda 0 \times 0.008 \lambda 0$ at $1.57 \mathrm{GHz}$. Figure 2 depicts the designed antenna with and without the split-shaped circular ring.

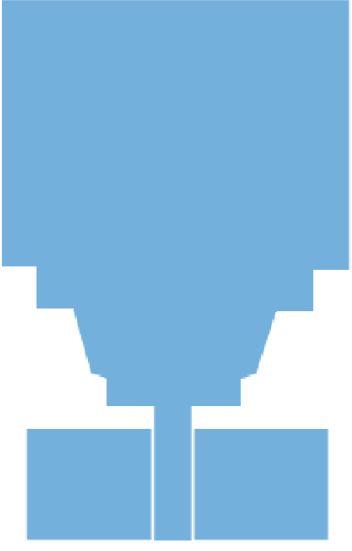

(a)

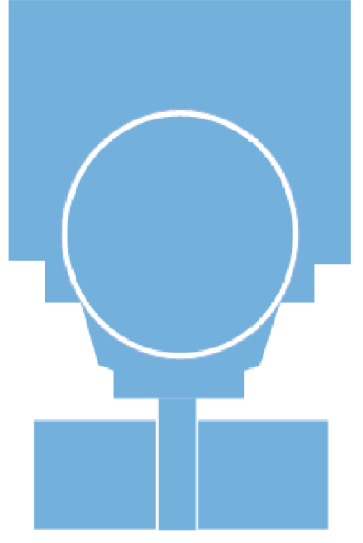

(b)
Figure 2: Antenna before and after etching the splitshaped circular ring, (a) First antenna, (b) Final antenna.

In order to understand the role of the etched splitshaped circular ring, the antenna is simulated before and after its introduction and the obtained results are illustrated in Figure 3.

It can be clearly shown that the split-shaped circular ring permits the transition from UWB to multiband function. The proposed radiating patch has a stepped shape that is created by cutting the metal from its lower part characterized by a high current distribution. The purpose of this cut is to affect the mutual and the capacitive coupling between the radiating patch and the truncated ground plane. In results, a good adaptation and a larger impedance bandwidth are achieved. Likewise, a lighter weight can be obtained; that is essentially wanted from the miniaturization viewpoint. Besides, more level of flexibility in the design and possibly minimized conductor losses are achieved. Based on the other published works like [17], the lower resonant frequency $f_{r}$ (in $\mathrm{GHz}$ ) of conventional printed monopole antennas can be evaluated by the equation (1).

$$
f_{r}=\frac{7.2}{L+W / 2 \pi+s}
$$

Here, $L$ and $W$ are the length and the width of the monopole; $\mathrm{s}$ is the gap separating the ground plane and the lower part of the radiator. The dimensions $L, W$, and $s$ are taken in $\mathrm{cm}$.
All the physical dimensions of the designed CPW-fed multiband stepped antenna were adjusted and optimized individually, by the use of the commercially software CST Microwave Studio ${ }^{T M}$, to attain good performances especially in terms of working bandwidths, radiation patterns, and gain. The detailed dimensions of the proposed multiband antenna are listed in Table 1.

Table 1: Optimized dimensions of the proposed multiband antenna.

\begin{tabular}{|c|c|}
\hline Parameters & Dimensions $(\mathrm{mm})$ \\
\hline $\mathrm{W}_{1}$ & 23.5 \\
\hline $\mathrm{W}_{2}$ & 2.19 \\
\hline $\mathrm{W}_{3}$ & 1.98 \\
\hline $\mathrm{W}_{4}$ & 0.77 \\
\hline $\mathrm{W}_{5}$ & 3.83 \\
\hline $\mathrm{W}_{6}$ & 8.84 \\
\hline $\mathrm{w}_{7}$ & 2.8 \\
\hline $\mathrm{W}_{8}$ & 21 \\
\hline $\mathrm{L}_{1}$ & 17 \\
\hline $\mathrm{L}_{2}$ & 1.98 \\
\hline $\mathrm{L}_{3}$ & 4.29 \\
\hline $\mathrm{L}_{4}$ & 1.77 \\
\hline $\mathrm{L}_{5}$ & 1.5 \\
\hline $\mathrm{R}_{1}$ & 9 \\
\hline $\mathrm{R}_{2}$ & 8.5 \\
\hline
\end{tabular}

Figure 3 indicates that by etching the split-shaped circular ring on the stepped radiating element, a transition from the UWB to multiband operation is produced.

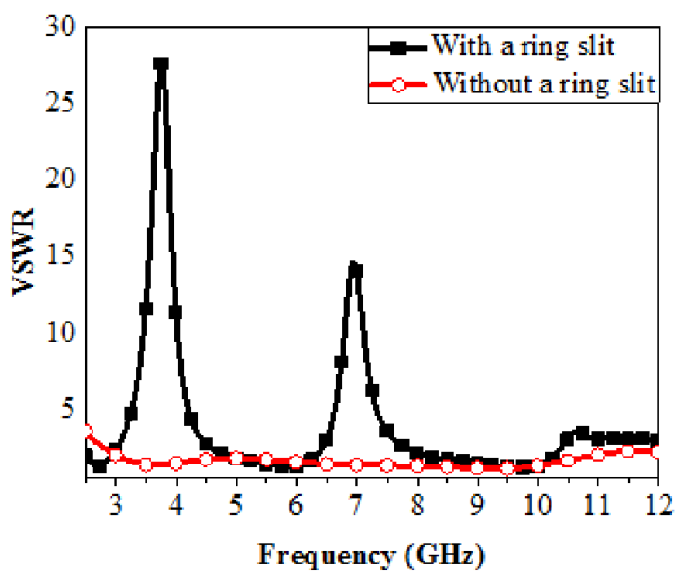

Figure 3: Role of the etched split-shaped circular ring on the VSWR characteristic of the proposed antenna.

The real and the imaginary parts of the impedance are depicted in Figure 4. Except around the notched bands, 
the real impedance is about the input impedance of the excitation port value (50 $\Omega$ ) over the operating bands. Beside, the imaginary part is almost vacillating around zero line throughout the operating bands. The Figure 5 reveals a collection of powers at the input and the output of the antenna. A good concordance can be shown between the accepted power and the radiated one which confirms a well adaptation of the antenna. Since the efficiency parameter is evaluated from the ratio of the radiated power to the accepted one, thus high level values of efficiency can be predicted the working bands. Besides, very low power outgoing the port (i.e. power reflected back out of the input port) around the working bands is revealed, and is nearly equal to the accepted one around the rejected bands.

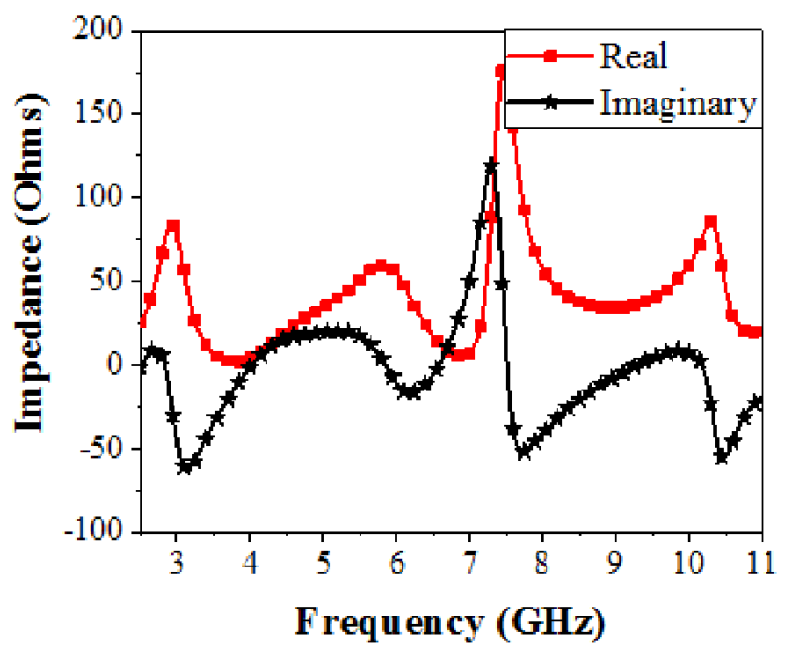

Figure 4: Real and imaginary impedance.

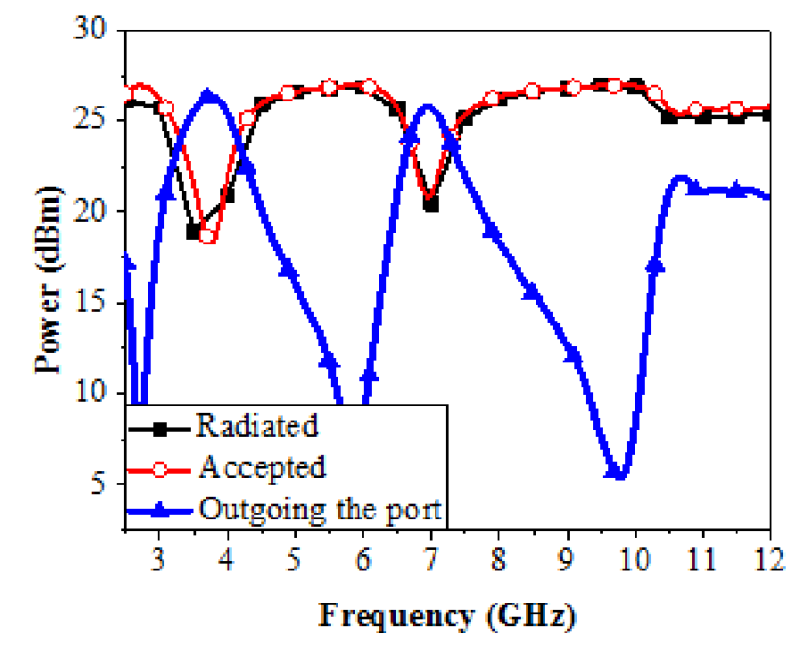

Figure 5: Powers at input and output of the designed antenna.

The presentation of the current distribution on the antenna's surface helps to show the structure responsible for the generation of the triple-band operation.
The current distribution on the surface of the designed antenna at the resonant frequencies of the two rejected bands is shown in Figure 6. It can be shown that at the two rejected resonant frequencies the current distribution is mightily concentrated on the splitshaped circular ring. A feeble current flowed along the rest parts of the radiating element is observed upholds the full contribution of the etched split-shaped circular ring on the rejection of the two bands and for the production of the triple-band operation. Figure 7 shows a photo of the fabricated prototypes (UWB and multiband antennas) that are graved, by using a laser printer (LPKF S103), on the FR4-substrate with a whole size of $0.162 \lambda 0 \times 0.123 \lambda 0 \times 0.008 \lambda 0$ at $1.57 \mathrm{GHz}$.

(a)

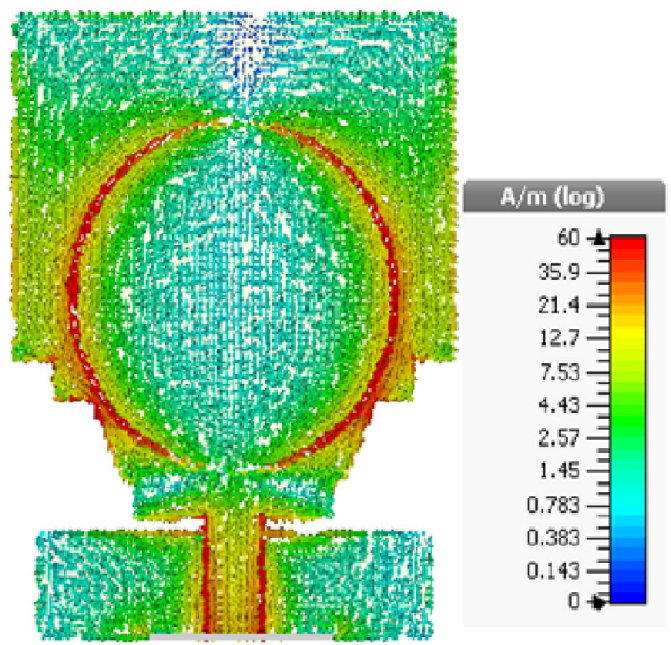

(b)

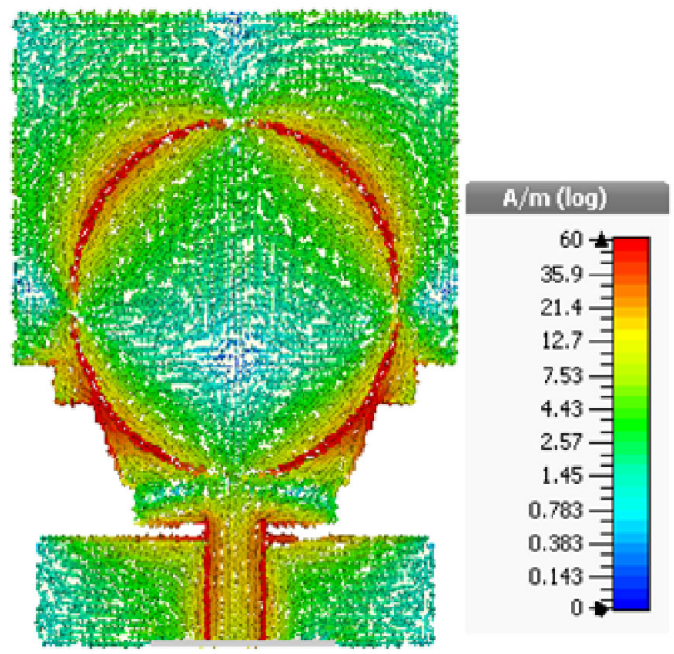

Figure 6: Surface current distribution on the surface of the antenna at two frequencies (a) $3.5 \mathrm{GHz}$, (b) $7 \mathrm{GHz}$.

To check the antennas operating frequencies, the voltage standing wave of the fabricated antennas was measured using an $R \& S^{\circledR} Z N B$ Vector Network Analyzer. Good agreements between the simulation and experimental results are achieved and the multiband char- 
(a)

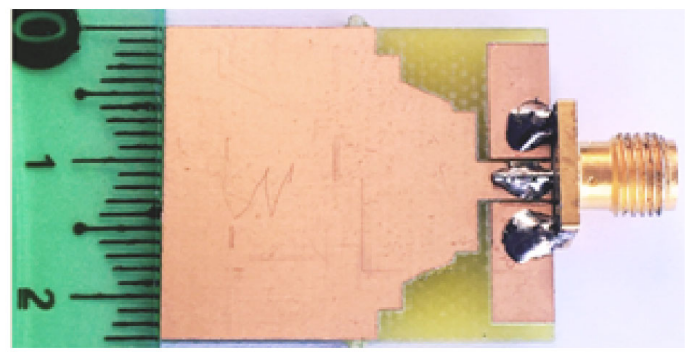

(b)

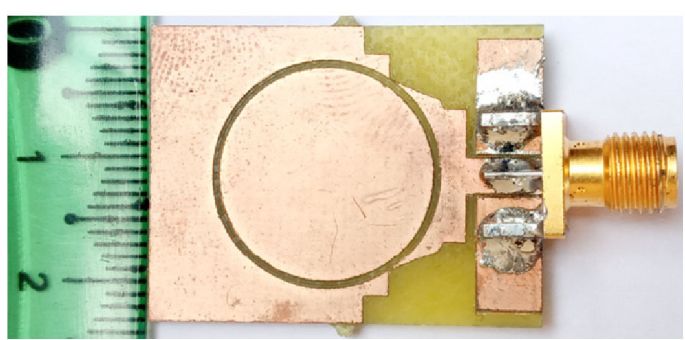

Figure 7: Fabricated prototypes (a) UWB antenna, (b) triple-band antenna.

acteristic of the antenna is demonstrated after etching the split-shaped circular ring. The small mismatch between the simulated results and the measured ones may be attributed to the intolerance in the fabrication and measurement processes, losses in port connection, and to inadmissible effects of the soldering that can affect the current distributions by creating parasitic inductance and capacitance links, and may be also due to the external disturbances which were not taken into account in the simulations. From the experimental results (Figure 8), the VSWR of the antenna covers the bands $1.57-2.33 \mathrm{GHz}(38.97 \%), 5.84-6.41 \mathrm{GHz}(9.31 \%)$, and $7.93-10.88 \mathrm{GHz}$ (31.37\%) covering the bands allocated to GSM1800, GSM1900, UMTS, GPS, GLONASS, DCS, PCS, TD-SCDMA, WCDMA, CDMA2000, DSRC, ITU8, and $X$ band radar.

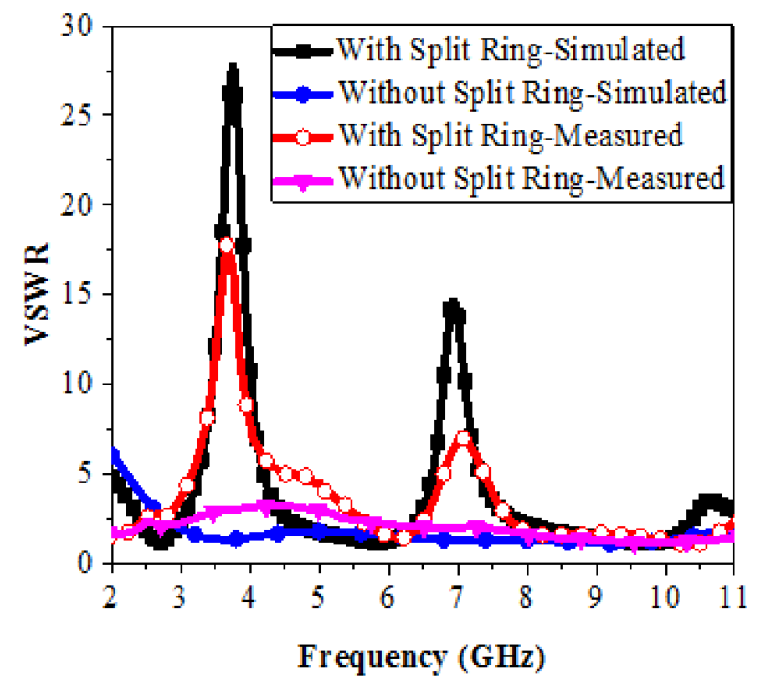

Figure 8: Measured and simulated VSWR of the proposed antenna with and without split-shaped circular ring.
It is evidently perceived that the introduction of the simple split-shaped circular ring on the patch of the designed antenna is responsible for the transition from the UWB to the multiband purpose and for the generation of the triple-band operation.

The radiation patterns were measured in an isolated anechoic chamber by using two antennas which are a double ridged horn antenna- model AH-118 (1-18) $\mathrm{GHz}$ and the fabricated antenna. Figure 9 and 10 show, respectively, the normalized co-polarization and cross polarization radiation patterns in both orthogonal planes at three different frequencies from the operating ranges: $1.99 \mathrm{GHz}, 6.2 \mathrm{GHz}$, and $10.33 \mathrm{GHz}$.

(a)

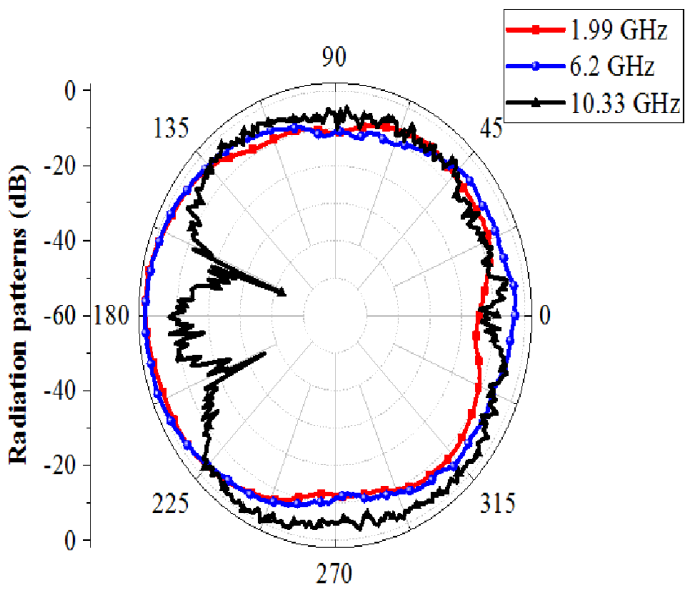

(b)

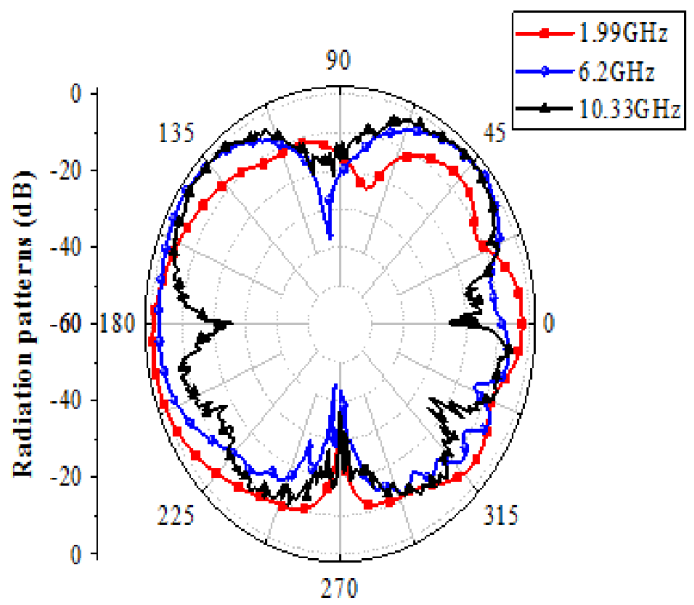

Figure 9: Measured normalized co-polarization radiation patterns at three frequencies, (a) $x z$-plane, (b) $y z-$ plane.

We can see that the co-polarization radiation patterns are practically omnidirectional in xz-plane $(\mathrm{H}-$ plane) and bidirectional shape in yz-plane (E-plane). It is noted that the measured radiation patterns exhibit expected stable patterns along the working bands. Besides, with augmenting the frequency, the number and the impact of side-lobes and nulls strengthen and 
(a)

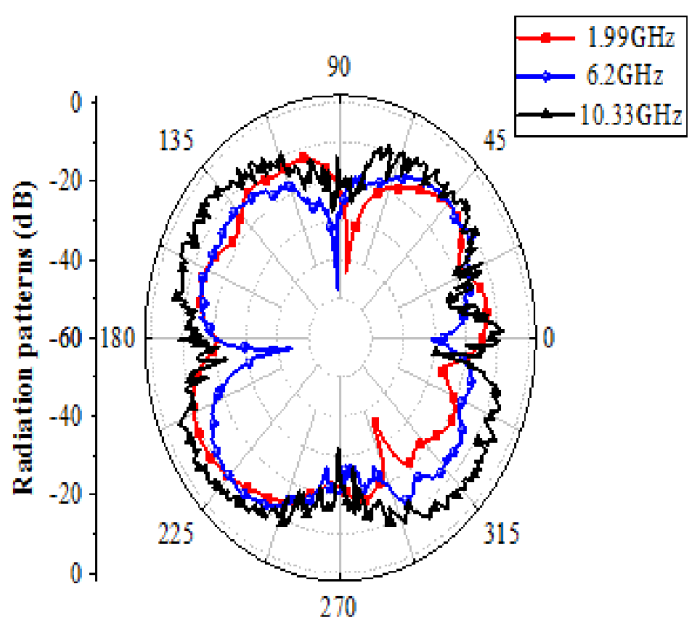

(b)

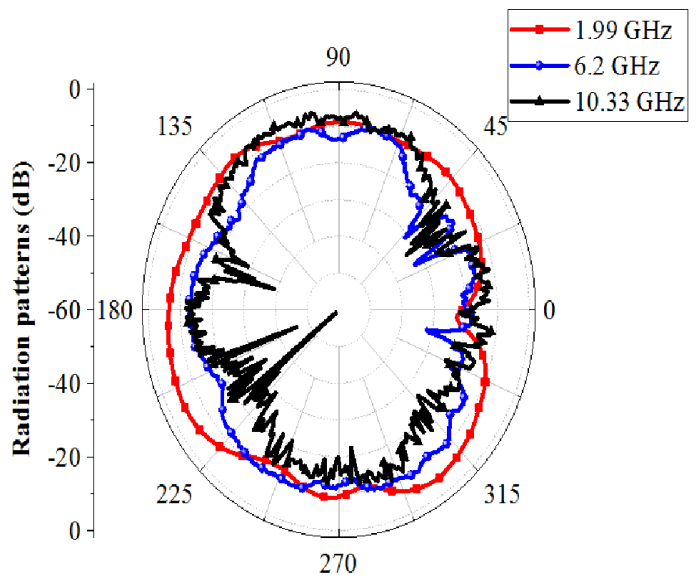

Figure 10: Measured normalized cross-polarization radiation patterns at three frequencies, (a) $x z$-plane, (b) yz-plane.

the measured antenna tends to provide bidirectional patterns in the xz-plane. Besides, analogous to the obtained results in [18-19], the cross-polarized patterns conserve their omnidirectional features over the three working bands. Figure 11 depicts the simulated realized gain and efficiency. Except at the notched bands, a reasonable and an acceptable increasing realized gain is obtained over the operating ranges; the simulated realized gain is better than the one calculated in [20].

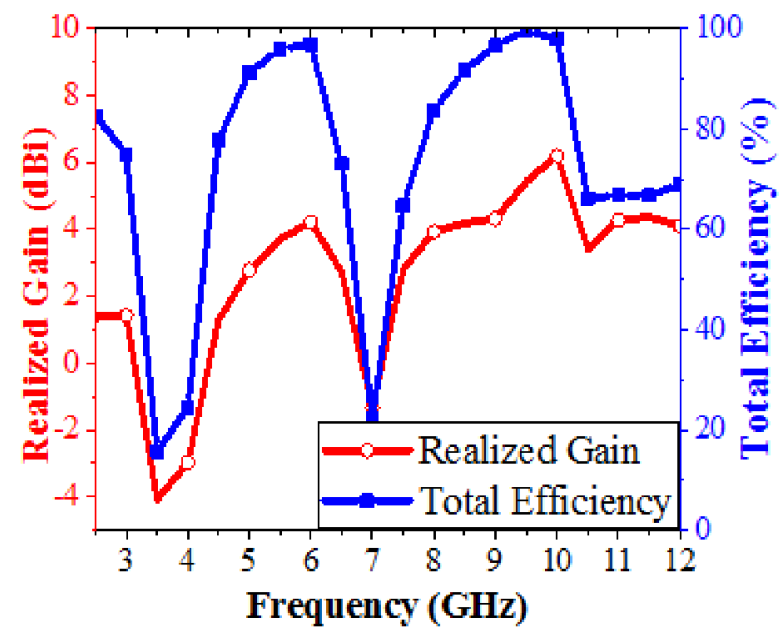

Figure 11: Realized gain and efficiency achieved by the proposed antenna.

Within the two notched ranges, the lowest values of the realized gain are located at around the two resonating frequencies of the split-shaped circular ring for $-4.09 \mathrm{dBi}$ and $-1.35 \mathrm{dBi}$ which at once validates the utility of the inserted split-shaped circular ring to produce the multiband function. As well, except at the two rejected bands, the simulated antenna efficiency is steady which is almost over than $80 \%$ along the working ranges; with two lowest values located of the two resonance frequencies of the etched split-shaped circu-

Table 2: Proposed antenna's comparative analysis with other recent reported antennas.

\begin{tabular}{|c|c|c|l|}
\hline References & Substrates & \multicolumn{1}{|c|}{ Sizes $(\mathrm{mm} 3)$} & \multicolumn{1}{|c|}{ Bandwidths } \\
\hline$[22]$ & Rogers 4003 & $40 \times 50 \times 0.812$ & $\begin{array}{l}2.39-2.59 \mathrm{GHz}(8.03 \%), 3.1-3.57 \mathrm{GHz}(14.09 \%), 5.45- \\
6.5 \mathrm{GHz}(17.57 \%)\end{array}$ \\
\hline$[23]$ & Rogers 6010LM & $50 \times 50 \times 2.54$ & $0.7-0.96 \mathrm{GHz}(31.32 \%), 1.18-3 \mathrm{GHz}(87.08 \%)$ \\
\hline$[24]$ & FR4 & $61 \times 41 \times 1.6$ & $1.379-1.564 \mathrm{GHz}(12.57 \%), 2.947-3.075 \mathrm{GHz}(4.25 \%)$ \\
\hline$[25]$ & FR4 & $125 \times 108 \times 1.6$ & $\begin{array}{l}1.53-1.97 \mathrm{GHz}(25.14 \%), 2.22-2.56 \mathrm{GHz}(14.23 \%), \\
3.31-4 \mathrm{GHz}(18.88 \%)\end{array}$ \\
\hline$[26]$ & FR4 & $60 \times 60 \times 1.56$ & $\begin{array}{l}2.31-2.89 \mathrm{GHz}(22.3 \%), 4.15-4.27 \mathrm{GHz}(2.85 \%), 4.64- \\
4.74 \mathrm{GHz}(2.13 \%)\end{array}$ \\
\hline$[27]$ & FR4 & $40 \times 40 \times 1.6$ & $2.88-3.92 \mathrm{GHz}(30.59 \%), 5.26-6.28 \mathrm{GHz}(17.68 \%)$ \\
\hline$[28]$ & FR4 & $50 \times 50 \times 1.6$ & $2.56-3.63 \mathrm{GHz}(34.57 \%), 9.35-12.25 \mathrm{GHz}(26.85 \%)$ \\
\hline$[29]$ & FR4 & $60 \times 60 \times 1$ & $2.51-3.72 \mathrm{GHz}(38.84 \%), 4.83-6.37 \mathrm{GHz}(27.5 \%)$ \\
\hline$[30]$ & FR4 & $60 \times 60 \times 1.59$ & $1.96-2.33 \mathrm{GHz}(17.25 \%), 3.74-10.4 \mathrm{GHz}(94.20 \%)$ \\
\hline$[31]$ & FR4 & $50 \times 35 \times 1.6$ & $2.35-3.22 \mathrm{GHz}(34.52 \%), 4.78-5.79 \mathrm{GHz}(18.39 \%)$ \\
\hline Fabricated & FR4 & $23.5 \times 31 \times 1.5$ & $\begin{array}{l}1.57-2.33 \mathrm{GHz}(38.97 \%), 5.84-6.41 \mathrm{GHz}(9.31 \%), 7.93- \\
10.88 \mathrm{GHz}(31.37 \%) .\end{array}$ \\
\hline
\end{tabular}


lar ring of about $15.71 \%$ and $22.22 \%$. It is revealed that the obtained efficiency surpass the one attained by some recently published papers like in [21]. Additionally, in order to show the importance of the proposed antenna, a comparative review has been established in Table 2. It is clear that the designed antenna has a small size compared to some recently published structures.

\section{Conclusion}

A simple compact printed CPW-fed triple-band antenna has been successfully designed, fabricated, and experimentally assessed for the integration with multiple wireless communication systems. The multiband function has been introduced by etching of a splitshaped circular ring on the radiating patch and exploring its effect on the initial designed UWB antenna. The advantage of the introduced concept is the simplicity of the transition from the UWB to multiband function. The measured working impedance bandwidths extends from 1.57-2.33 GHz (38.97\%), 5.84-6.41 GHz (9.31\%), and $7.93-10.88 \mathrm{GHz}(31.37 \%)$, covering the spectrum reserved to GSM1800, GSM1900, UMTS, GPS, GLONASS, DCS, PCS, TD-SCDMA, WCDMA, CDMA2000, DSRC, ITU8, and $X$ band radar. The proposed antenna reveals consistent measured radiation patterns with acceptable realized gain and high efficiency over the operating bands. The simple geometry and the compact structure of the designed antenna meets the requirement of many wireless communication systems.

\section{Acknowledgments}

This work was supported by the Directorate General for Scientific Research and Technological Development (DG-RSDT) of Algeria. The authors would like to thank Pr. Tayeb A. Denidni, INRS Canada, for his kind help for the antenna radiation patterns measurements.

\section{Conflict of interest}

The authors declare no conflict of interest.

\section{References}

1. F. B. Zarrabi, A. M. Shire, M. Rahimi, N. P. Gandji, "Ultra-wideband tapered patch antenna with fractal slots for dual notch application", Micro- wave and Optical Technology Letters, vol. 56, no. 6, pp. 1344-1348, 2014, https://doi.org/10.1002/mop.28332

2. R. Azim, M. T. Islam, N. Misran, A. T. Mobashsher, "Compact UWB planar antenna for broadband applications", Informacije MIDEM-Journal of Microelectronics, Electronic Components and Materials, vol. 41, no. 1, pp. 37-40, 2011,

3. W. Zaman, H. Ahmad, H. Mehmood, "A miniaturized meandered printed monopole antenna for triband applications", Microwave and Optical Technology Letters. vol. 60, no. 5, pp. 1265-1271, 2018,

https://doi.org/10.1002/mop.31149

4. Z. P. Zhong, J.J. Liang, M. L. Fan, G. L. Huang, W. He, X. C. Chen, T. Yuan. A compact CPW-fed UWB antenna with quadruple rejected bands. Microwave and Optical Technology Letters, vol. 61, no. 12, pp. 2795-2800,2019, https://doi.org/10.1002/mop.31976

5. V. K. Pandit, A. R. Harish, "A compact CPW-fed tapered monopole triple-band antenna for WLAN/ WiMAX application", Microwave and Optical Technology Letters. vol.60, no. 9, pp. 2298-2303, 2018, https://doi.org/10.1002/mop.31340

6. J. P. Keshari, B. K. Kanaujia, M. K. Khandelwal,P. S. Bakariya,"Omnidirectional multi-band stacked microstrip patch antenna with wide impedance bandwidth and suppressed cross-polarization", International Journal of Microwave and Wireless Technologies, vol. 9, no. 03, pp. 628-638, 2016, https://doi.org/10.1017/S1759078716000209

7. N. K. Mungaru, K. Yogaprasad, V. R. Anitha, "A quadband Sierpenski based fractal antenna fed by coplanar waveguide", Microwave and Optical Technology Letters, vol. 62, no. 2, pp. 893-898, 2019, https://doi.org/10.1002/mop.32097

8. B. T. P. Madhav, T. Anilkumar, "Design and study of multiband planar wheel-like fractal antenna for vehicular communication applications", Microwave and Optical Technology Letters, vol. 60, no. 8, pp. 1985-1993, 2018, https://doi.org/10.1002/mop.31290

9. X. Ran, Z. Yu, T. Xie, Y. Li, X. Wang, P. Huang, "A novel dual-band binary branch fractal bionic antenna for mobile terminals", International Journal of Antennas and Propagation, vol. 2020, pp. 1-9, 2020, https://doi.org/10.1155/2020/6109093

10. S. Sah, A. Mittal, M. R. Tripathy, "High gain dual band slot antenna loaded with frequency selective surface for WLAN/ fixed wireless communication", Microwave and Optical Technology Letters, vol. 61, no. 2, pp. 519-525, 2018, https://doi.org/10.1002/mop.31559 
11. A. K. Arya, S. J. Kim, S. Kim, "A dual-band antenna for LTE-R and 5 G lower frequency operations", Progress in Electromagnetics Research Letters, vol. 88, pp. 113-119, 2020, https://doi.org/10.2528/PIERL19081502

12. A. Hatami, M. Naser-Moghadasi, "Split ring resonator metamaterial loads for compact Hepta band printed inverted $\mathrm{F}$ antenna with circular polarization", Microwave and Optical Technology Letters, vol. 60, no. 10, pp. 2552-2559, 2018, https://doi.org/10.1002/mop.31367

13. Y. F. Cao, S. W. Cheung, T. I. Yuk, "A multi-band slot antenna for PS/WiMAX/WLAN systems", IEEE Transactions on Antennas and Propagation, vol. 63, no. 03, pp. 952-958, 2015, https://doi.org/10.1109/TAP.2015.2389219

14. H. W. Liu, C. H. Ku, C. F. Yang, "Novel CPW-fed planar monopole antenna for WiMAX/WLAN applications", IEEE Antennas and Wireless Propagation Letters, vol. 9, pp. 240-243, 2010, https://doi.org/10.1109/LAWP.2010.2044860

15. C. J. Wang, C. W. Hsu, "Design of a multiband ground radiation antenna by utilizing balun excitation", Microwave and Optical Technology Letters, vol. 61, no. 4, pp. 1034-1041, 2018, https://doi.org/10.1002/mop.31661

16. R. S. Brar, K. Saurav, D. Sarkar, K. V. Srivastava, "A quad-band dual-polarized monopole antenna for GNSS/UMTS/WLAN/WiMAX applications", Microwave and Optical Technology Letters, vol. 60, no. 3, pp. 538-545, 2018, https://doi.org/10.1002/mop.31008

17. P. Pushkar, V. R. Gupta, "A metamaterial based triband antenna for WiMAX/WLAN application", Microwave and Optical Technology Letters, vol. 58, no. 3, pp. 558-561, 2016, https://doi.org/10.1002/mop.29616

18. A. Pandey, S. Singhal, A. K. Singh, "CPW-FED third iterative square-shaped fractal antenna for UWB applications", Microwave and Optical Technology Letters, vol. 58, no. 1, pp. 92-99, 2015, https://doi.org/10.1002/mop.29510

19. T. Okan, "A compact octagonal-ring monopole antenna for super wideband applications", Microwave and Optical Technology Letters, vol. 62, no. 3, pp. 1237-1244, 2019, https://doi.org/10.1002/mop.32117

20. Z. P. Zhong, J. J. Liang, M. L. Fan, G. L. Huang, W. He, X. C. Chen, T. Yuan, "A compact CPW-fed UWB antenna with quadruple rejected bands", Microwave and Optical Technology Letters, vol. 61, no. 12, pp. 2795-2800, 2019,

https://doi.org/10.1002/mop.31976

21. B. Hammache, A. Messai, I. Messaoudene, T. A. Denidni, "Compact ultrawideband slot antenna with three notched-band characteristics", International
Journal of RF and Microwave Computer-Aided Engeneering, vol. 30, no. 5, e22146, 2020, https://doi.org/10.1002/mmce.22146

22. D. O. Kim, C. Y. Kim, D. G. Yang, M. S. Ahmad, "Multiband omnidirectional planar monopole antenna with two split ring resonator pairs", Microwave and Optical Technology Letters, vol. 59, no. 4, pp. 753-758, 2017,

https://doi.org/10.1002/mop.30390

23. S. M. Haque, H. Alam, "Miniaturized dual-band slot antenna design for GPS, amateur radio and WLAN applications", International Journal of RF and Microwave Computer-Aided Engeneering, vol. 30, no. 4, e22125, 2020, https://doi.org/10.1002/mmce.22125

24. K. Djafri, M. Challal, A. Azrar, M. Dehmas, R. Aksas, F. Mouhouche, "Compact dual-band fractal hexagonal ring monopole antenna for RFID and GSM applications", Microwave and Optical Technology Letters, vol. 60, no. 11, pp. 2656-2659, 2018, https://doi.org/10.1002/mop.31497

25. J. Park, M. Jeong, N. Hussain,S. Rhee, P. Kim, N. Kim, "Design and fabrication of triple-band folded dipole antenna for GPS/ DCS/WLAN/WiMAX applications", Microwave and Optical Technology Letters, vol. 61, no. 5, pp. 1328-1332, 2019, https://doi.org/10.1002/mop.31739

26. P. M. Paul, K. Kandasamy, M. S. Sharawi, "A tri-band slot antenna loaded with split ring resonators", Microwave and Optical Technology Letters, vol. 59, no. 10, pp. 2638-2643, 2017, https://doi.org/10.1002/mop.30791

27. S. P. Gangwar, K. Gangwar, A. Kumar, "Dual-band modified circular slot antenna for WLAN and WiMAX applications", Progress in Electromagnetics Research C, vol. 85, pp. 247-257, 2018, https://doi.org/10.2528/PIERC18061805

28. Q. Chen, H. Zhang, L. C. Yang, H. P. Li, T. Zhong, X. L. Min, S. L. Tan, "Novel dual-band asymmetric U-shaped slot antenna for dual-circular polarization", International Journal of RF and Microwave Computer-Aided Engeneering, vol. 27, no. 1, e21047, 2016, https://doi.org/10.1002/mmce.21047

29. X. Rui, J. Li, K. Wei, "Dual-band dual-sense circularly polarised square slot antenna with simple structure", Electronics Letters, vol. 52, no. 8, pp. 578-580, 2016, https://doi.org/10.1049/el.2015.4499

30. K. Srivastava, A. Kumar, B. K. Kanaujia,S. Dwari, S. Kumar, "Multiband integrated wideband antenna for Bluetooth/WLAN applications", AEU - International Journal of Electronics and Communications, vol. 89, pp. 77-84, 2018, https://doi.org/10.1016/j.aeue.2018.03.027 
31. B. Bag, P. Biswas, R. Mondal, S. Biswas, P. P. Sarkar, “Dual-band dual-sense circularly polarized U- and L-shaped strip monopole antenna for WiMAX/ WLAN applications", Journal of Electromagnetic Waves and Applications, vol. 33, no. 18, pp. 24342448, 2019,

https://doi.org/10.1080/09205071.2019.1684387

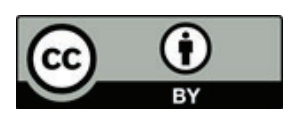

Copyright $@ 2020$ by the Authors. This is an open access article distributed under the Creative Commons Attribution (CC BY) License (https://creativecommons.org/licenses/by/4.0/), which permits unrestricted use, distribution, and reproduction in any medium, provided the original work is properly cited.

Arrived: 16. 09. 2020

Accepted: 29. 12. 2020 